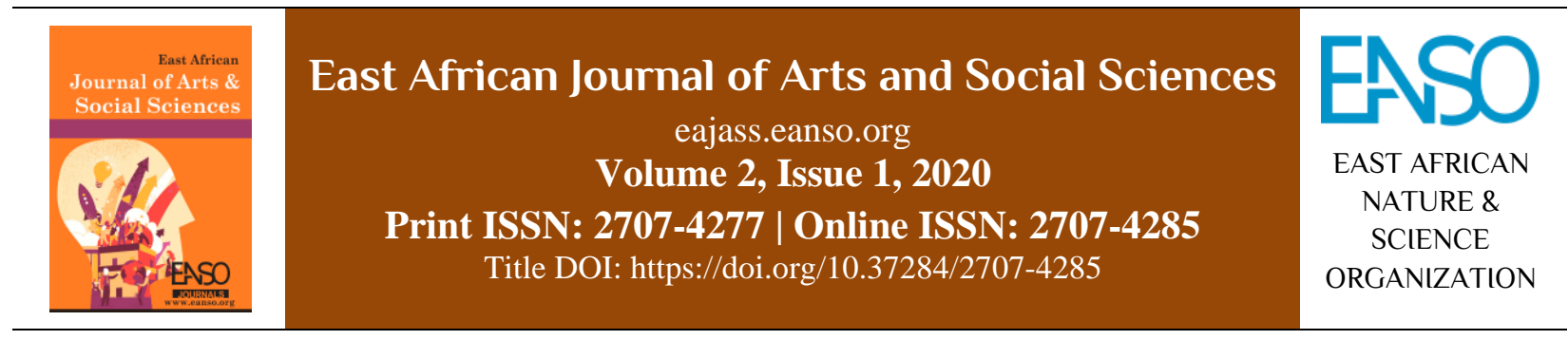

Original Article

\title{
Family Characteristics as Predictors of Youth Livelihood Outcomes in Kenya
}

\author{
Christine W. Njuguna, $P h D^{1} \&$ Lucy W. Ngige, $P h D^{2 *}$ \\ ${ }^{1}$ Kenyatta University, P. O. Box 43844 - 00100, Nairobi, Kenya; ORCID: https://orcid.org/0000-0001-7173-0498. \\ ${ }^{2}$ Kenyatta University, P. O. Box 43844 - 00100, Nairobi, Kenya; ORCID: https://orcid.org/0000-0003-1750-1496. \\ *Author for Correspondence email: ngigelucy@gmail.com.
}

Article DOI: https://doi.org/10.37284/eajass.2.1.191

\section{Article history: ABSTRACT}

07 August 2020

Keywords:

Family Characteristics,

Parental Support, Livelihood Outcomes,

Youth,

Kenya.
The purpose of the study was to investigate the effect of family characteristics on youth livelihood outcomes (YLO) in Kenya. A survey was conducted on a random sample of 201 respondents aged between 18 to 35 years who were selected from a list of members of registered self-help youth groups. Data was gathered through a questionnaire and analysed by the se of the Statistical Package for the Social Sciences (SPSS). Youth livelihood outcomes occurred along a continuum of three levels, namely: survival, security and growth livelihood levels. Results revealed that $52 \%$ of the respondents attained survival livelihood level, $18 \%$ attained the security level, and 30\% attained the growth level of youth livelihood outcomes. Research findings indicated that family characteristics improved prediction power of youth livelihoods outcomes by $72.1 \%\left(\mathrm{R}^{2}=0.721 ;\right.$ Log-Likelihood Ratio $\left(\chi^{2}=203.18 ; \mathrm{d} . \mathrm{f}=12 ; \mathrm{p}=0.000\right)$. The significant predictors of youth livelihood outcomes were the aggregate family income $(\beta=1.00, \mathrm{p}=0.000)$, paternal education $(\beta=1.60, \mathrm{p}=0.016)$, parental support $(\beta=1.93, p=0.047)$, number of dependents $(\beta=0.02, p=0.001)$, and aggregate family assets $(\beta=1.00, \mathrm{p}=0.019)$. However, family expenditure $\left(\chi^{2}\right.$ $=2.37$; d.f. $=2 ; \mathrm{p}>0.05)$ and maternal education $\left(\chi^{2}=9.72\right.$; d.f. $\left.=3 ; \mathrm{p}>0.05\right)$ had no statistically significant relationship with youth livelihood outcomes. These results implied that that youth from middle-income families, whose fathers had acquired higher levels of education, and whose families had fewer dependents, had accumulated family assets and whose parents supported their livelihood strategies attained higher levels of youth livelihood outcomes compared to their counterparts who were less privileged on similar family characteristics. The outcomes of this study may be used to develop appropriate family and youth-focused interventions to enhance youth livelihood outcomes. 
East African Journal of Arts and Social Sciences, Volume 2, Issue 1, 2020

Article DOI: https://doi.org/10.37284/eajass.2.1.191

APA CITATION

Njuguna, C., \& Ngige, L. (2020). Family Characteristics as Predictors of Youth Livelihood Outcomes in Kenya. East African Journal of Arts and Social Sciences, 2(1), 48-59. https://doi.org/10.37284/eajass.2.1.191

\section{CHICAGO CITATION}

Njuguna, Christine, and Lucy Ngige. 2020. "Family Characteristics as Predictors of Youth Livelihood Outcomes in Kenya".

East African Journal of Arts and Social Sciences 2 (1), 48-59. https://doi.org/10.37284/eajass.2.1.191.

\section{HARVARD CITATION}

Njuguna, C. and Ngige, L. (2020) "Family Characteristics as Predictors of Youth Livelihood Outcomes in Kenya", East African Journal of Arts and Social Sciences, 2(1), pp. 48-59. doi: 10.37284/eajass.2.1.191.

\section{IEEE CITATION}

C. Njuguna and L. Ngige, "Family Characteristics as Predictors of Youth Livelihood Outcomes in Kenya", EAJASS, vol. 2, no. 1, pp. 48-59, Aug. 2020.

\section{MLA CITATION}

Njuguna, Christine, and Lucy Ngige. "Family Characteristics as Predictors of Youth Livelihood Outcomes in Kenya". East African Journal of Arts and Social Sciences, Vol. 2, no. 1, August 2020, pp. 48-59, doi:10.37284/eajass.2.1.191.

\section{INTRODUCTION}

Youths in Kenya and across the world face challenges of inequity, unemployment, underemployment and working poverty. This situation impairs their livelihood aspirations and subsequent livelihood outcomes thereby deterring their participation in sustainable national development (Omolo, 2010; United States Agency for International Development [USAID], 2013; International Labour Organization [ILO], 2015 and UN-Habitat, 2015). These challenges affect youth livelihood outcomes negatively by inhibiting social inclusion, access to optimal utilization of capitals and lack of democratic space for youths' participation in social-economic development. According to Scoones (2009), livelihood outcomes constitute basic needs such as food security, access to clean and safe water, health care services, decent housing, education, personal safety and community participation.

Kenya's youth unemployment rate is the highest in East Africa as estimated by World Bank (2015) at $17.4 \%$ which is equivalent to five times the average in East Africa. ILO (2015) estimated that in 2013, about $38 \%$ of youth were poor and categorised as persons living below two dollars a day. This translates to over a third of employed youth in the developing world. Further, three in four employed youth in low-income countries work in inadequate environments within self-employment, casual jobs and family-owned micro-enterprises, a phenomenon called "working poverty" (ILO, 2015). Working poverty has an undesirable consequence on youth livelihood outcomes which impede countries from reaping demographic dividends from youth. ILO (2015) calls for a more renewed commitment by developing countries to create employment for the increasing youth population in developing countries. The youth labour force grows incrementally, whereas opportunities for paid work are dismal and working poverty is pervasive.

From the turn of the millennium, the 18 to 35 -yearold youth cohort has grown exponentially to constitute a third of the Kenyan population resulting in a youth bulge (Njonjo, 2010). Having a population that is skewed towards the young can result in achieving a demographic dividend or a demographic bomb. A demographic bomb happens as a result of high levels of unemployment, economic and social exclusion, all of which are indicators of undesirable youth livelihood outcomes. The youth bulge results in a demographic dividend since as the young adults enter the working age, the country's dependency ratio declines. This too is an indicator of undesirable youth livelihood outcomes. The effects 
of youth bulge have compounded youth unemployment and underemployment in Kenya hampering full utilisation of human capital since independence (Republic of Kenya, 1965; 1969; 2008a; 2008b). The majority of Kenyan youth seek livelihoods in the informal sector that lacks the security of tenure and social protection besides having unfavourable terms of employment, poor health and safety standards, all of which pose a threat to youth livelihood outcomes (Omolo, 2011).

In this research, youths' livelihood outcomes have been considered from a livelihood framework approach adapted from the Department for International Development [DFID] (1999) which posited that livelihoods are pursued within contexts and structural processes that influence socioeconomic outcomes. Meikle (2002) reported that livelihood strategies of youth are shaped by access to and combination of capitals in addition to urban contextual factors. Youth utilise various capitals accessible to them such as financial, social, physical, human and natural capitals to develop their livelihoods. This is achieved through productive and non-productive income, consumption, processing and exchange activities to arrive at the desired levels of livelihood outcomes (DFID, 1999). Therefore, when access and utilisation to vital capitals that shape livelihoods are not available due to unemployment, underemployment and working poverty, then the attainment of desired livelihood outcomes of youth becomes untenable. According to McKee (1989), livelihood outcomes occur along a continuum of three levels, namely: survival, security and growth livelihood levels. The survival livelihood level is attained when a family's primary concern is the attainment of basic needs; while security livelihood level occurs when a family diversifies its livelihood strategies to reduce risk and increase flexibility, and growth livelihood level occurs when a family can invest in more capital-intensive livelihood strategies. This study adapted McKee's (1989) classification of youth livelihood outcomes for the urban youth in Kenya.

Adequate research lacks on what constitutes livelihoods of low-income urban youth, particularly how family characteristics influence youth livelihood outcomes. Previous studies in Kenya have had a greater focus on youth unemployment rather than a specific focus on factors that influence youth livelihood outcomes (Omolo, 2010; 2011; Maisiba and Gongera, 2013; Muiya, 2014; Chiiran, 2014). Family characteristics include features that differ from one family to another such as family size, incomes, expenditures, asset ownership, parental role modelling and kinship support networks. In this research, the core questions that emerge include an assessment of family factors that influence youth livelihood outcomes and promote resilience to vulnerabilities. For youth who are nonresilient, what informs interventions on improving their livelihood outcomes? Without this information, appropriate interventions with lasting impact on youth livelihood outcomes become a challenge. These information gaps elicited interest in conducting research on family predictors of youth livelihood outcomes in Kenya that can inform stakeholders on the positive facilitators of youth livelihoods development. The purpose of the study, therefore, was to establish whether there was a significant relationship between family characteristics and urban youth livelihood outcomes. The objectives of the study were to: determine the family characteristics of the urban youth, establish the levels of youth livelihood outcomes, determine the relationship between family characteristics and youth livelihood outcomes, and finally to establish whether family characteristics were significant predictors of youth livelihood outcomes. The null hypothesis stated that there was no statistically significant relationship between family characteristics and youth livelihood outcomes and secondly, that family characteristics did not significantly predict youth livelihood outcomes. 


\section{METHODOLOGY}

This research used a cross-sectional survey research design. A random sample of 201 respondents aged between 18 to 35 years was selected from a list of members of registered self-help youth groups in Nairobi County, Kenya. Data was gathered through a structured questionnaire and analysed by use of the Statistical Package for the Social Sciences (SPSS) Version 24. To establish the independent variable, family characteristics were assessed by investigating socio-demographic variables such as gender, age, marital status, the number of dependents, maternal and paternal levels of education, occupation, aggregate family income, expenditure and assets. To establish the dependent variable (youth livelihood outcomes), questions were adapted from the DFID (1999) livelihoods framework. The 5-point Likert type questions assessed the extent to which youth had experienced various aspects of their livelihoods in the year before the study. Responses on the scale were coded as: "1=None at all", " $2=$ To a Little Extent", "3=To a Moderate Extent", "4= To a Large Extent" and " $5=$ To a Very Large Extent". The scores obtained from the responses to the fifteen questions along a 5-point Likert scale were calculated. The lowest and the highest possible scores an individual could have achieved for the 15 questions were 15 and 75, respectively. Using this approach, respondents who attained a range of below 25 points were categorised as belonging to the survival livelihood level, those who attained $26-50$ points were categorised as belonging to the security level and those respondents who attained 51-75 points were categorised as belonging to the growth level of youth livelihood outcomes.

\section{RESULTS}

A sample of 201 youth aged between 18 to 35 years participated in the study. The frequency distribution of demographic characteristics of the respondents is presented in Table 1.

Table 1: Distribution of Demographic Characteristics of Respondents

\begin{tabular}{llll}
\hline Variable & & Frequency (N) & Percent (\%) \\
Gender & Female & 53 & 26 \\
& Male & 148 & 74 \\
\hline Age & 25 years and below & 99 & 49 \\
& 26-30 years & 63 & 31 \\
& $>30$ years & 39 & 19 \\
\hline Marital status & Single & 131 & 65 \\
& Married & 61 & 31 \\
& Cohabiting (<6 months) & 7 & 3 \\
& Divorced & 2 & 2 \\
\hline Education & None & 7 & 3 \\
& Primary & 19 & 10 \\
& Secondary & 101 & 50 \\
& Tertiary & 74 & 37 \\
\hline Working Status & Wage employee & 14 & 7 \\
& Self-employed & 124 & 62 \\
& Homemaker & 7 & 3 \\
& Unemployed & 56 & 28 \\
\hline Family headship & Youth-headed families with dependents & 132 & 66 \\
& Youth headed families without dependents & 69 & 34 \\
\hline
\end{tabular}


The results in Table 1 showed that $74 \%$ of the respondents were males and $26 \%$ were females aged between 18 and 35 years. In terms of marital status, $65 \%$ were single, $31 \%$ were married, while $4 \%$ were either cohabiting or divorced. Regarding formal education attainment, $37 \%$ had tertiary education, $50 \%$ had secondary education, $10 \%$ had completed primary education, while $3 \%$ had no formal education. Findings indicated that $28 \%$ of the respondents were unemployed, $62 \%$ were selfemployed, whereas $7 \%$ were in wage employment.
The youth-headed families with dependents comprised of $66 \%$ while their counterparts who had no dependents accounted for $34 \%$.

\section{Levels of Youth Livelihood Outcomes}

The research sought to establish the levels of youth livelihood outcomes among the respondents. Table 2 presents the frequency distribution of youth livelihood outcomes.

\section{Table 2: Distribution of Youth Livelihood Outcomes}

\begin{tabular}{lll}
\hline Variable & Frequency (n) & Percent (\%) \\
\hline Survival Livelihood level & 105 & 52 \\
Security Livelihood level & 35 & 18 \\
Growth Livelihood level & 61 & 30 \\
Total & $\mathbf{2 0 1}$ & $\mathbf{1 0 0}$ \\
\hline
\end{tabular}

Research findings established that $52 \%$ of the youth were at survival level of youth livelihood outcomes, $18 \%$ at the security level and $30 \%$ at the growth level of youth livelihood outcomes. This demonstrated that more than half of the study participants were still struggling at the survival livelihood outcome level while less than a third of the respondents were at the growth livelihood level.

\section{Capitals in the Form of Family Characteristics} and Youth Livelihood Outcomes

Capitals in the form of family characteristics in the study referred to attributes or capitals that differ from family to family such as family size; a number of dependants; income and expenditure; parental/guardian education; parental support of youth livelihood strategies and aggregate family assets. Table 3 presents the frequency distribution by family characteristics across the three youth livelihood outcome levels.

Table 3: Distribution by Family Characteristics and Youth Livelihood Outcomes

\begin{tabular}{llllll}
\hline Variable & Total & \multicolumn{3}{l}{ Youth Livelihood Outcomes } \\
& & & Survival & Security & Growth \\
Level & Level & Level \\
\hline Family size (Mean) & & 3 & 3 & 2 & 2 \\
\hline Number of Dependents & $3-5$ dependents & $19(9 \%)$ & $14(13 \%)$ & $2(6 \%)$ & $3(5 \%)$ \\
& $1-2$ dependents & $181(91 \%)$ & $91(87 \%)$ & $33(94 \%)$ & $57(95 \%)$ \\
\hline Income and Expenditure & Income (KSh.) & $22,258.34$ & $18,138.57$ & $21,444.95$ & $26,598.23$ \\
& Expenditure (KSh.) & $20,262.70$ & $19,210.86$ & $18,400.50$ & $19,772.67$ \\
\hline Parental Education & Mother's education & & & & \\
& None & $42(25 \%)$ & $21(23 \%)$ & $13(40 \%)$ & $8(17 \%)$ \\
& Primary & $54(32 \%)$ & $31(34 \%)$ & $10(30 \%)$ & $13(29 \%)$ \\
\hline
\end{tabular}


East African Journal of Arts and Social Sciences, Volume 2, Issue 1, 2020

Article DOI: https://doi.org/10.37284/eajass.2.1.191

\begin{tabular}{|c|c|c|c|c|c|}
\hline \multirow[t]{2}{*}{ Variable } & & \multirow[t]{2}{*}{ Total } & \multicolumn{3}{|c|}{ Youth Livelihood Outcomes } \\
\hline & & & $\begin{array}{l}\text { Survival } \\
\text { Level }\end{array}$ & $\begin{array}{l}\text { Security } \\
\text { Level }\end{array}$ & $\begin{array}{l}\text { Growth } \\
\text { Level }\end{array}$ \\
\hline & Secondary & $50(29 \%)$ & $29(31 \%)$ & $4(12 \%)$ & $17(37 \%)$ \\
\hline & Tertiary & $25(15 \%)$ & $11(12 \%)$ & $6(8 \%)$ & $8(17 \%)$ \\
\hline & Father's education & & & & \\
\hline & None & $19(12 \%)$ & $8(10 \%)$ & $7(22 \%)$ & $4(10 \%)$ \\
\hline & Primary & $44(28 \%)$ & $3136 \%)$ & $7(22 \%)$ & $6(14 \%)$ \\
\hline & Secondary & $63(39 \%)$ & $35(41 \%)$ & $10(33 \%)$ & $18(43 \%)$ \\
\hline & Tertiary & $32(21 \%)$ & $11(13 \%)$ & $7(22 \%)$ & $14(33 \%)$ \\
\hline \multirow[t]{2}{*}{ Parental Support } & $\begin{array}{l}\text { Positive parental } \\
\text { support }\end{array}$ & $110(55 \%)$ & $48(46 \%)$ & $5(14 \%)$ & $37(62 \%)$ \\
\hline & No parental support & $90(45 \%)$ & $57(54 \%)$ & $30(86 \%)$ & $23(38 \%)$ \\
\hline \multicolumn{2}{|c|}{ Aggregate value of family assets (KSh.) } & $67,585.00$ & $19,765.00$ & $30,274.00$ & $68,093.00$ \\
\hline
\end{tabular}

(Note that KSh. 100 is equivalent to one (1.00) US Dollar in 2020)

\section{Family Size and Number of Dependents}

In this study, the term dependent comprised one or more members who relied on the youth-headed family for the provision of their basic needs. This dependency was in terms of provision of food, shelter, family utility bills, transport, medical care and school fees. Typical families in the study had a mean of three members whose range of dependents was from one to five members. Majority of the respondents (91\%) comprised of a small family size ranging from one to two dependents, while only $9 \%$ comprised of a medium-size family with dependents ranging from three to five members.

\section{Parental Education}

The Father (paternal) level of education was generally higher than the mother's (maternal) level of education. Results revealed that $25 \%$ of the mothers had no formal education compared to $12 \%$ of fathers with no formal education. This implied that there were twice as many mothers who were considered illiterate compared to the number of fathers in this sample. Mothers who had attained a secondary or higher level of education were much less at $44 \%$ compared to $60 \%$ of fathers with similar levels of education.

\section{Family Income}

The youth were asked to give information regarding their family income and expenditure, savings, debt and other investments. Findings showed that aggregate family monthly income from all sources (including salary, wage, gifts and sales) ranged from Kenya Shillings (KSh.) 3,500 to 200,000 with the distribution being positively skewed towards the low income of KSh. 3,500. A typical family in the study area had a mean income of KSh. 22,258 with the middle half receiving KSh. 12,000 to 25,250 . The study also sought to investigate the contribution of other family members to the aggregate family income. Findings indicated that a majority of members did not contribute to the family income. However, for those who did, their contribution was either in the form of family chores or paying utility bills, house rent and transport costs.

\section{Family Expenditure}

Family expenditure was conceptualised as money spent on food, clothes, shelter, healthcare, education, transport and utilities such as water, electricity and cooking fuel per month. The average family expenditure was KSh. 25,640 (S.D. 19,412), with a range of KSh. 10,800 and KSh. 76,800. 
Further analysis of the family expenditure by item established that food, education and shelter took the largest proportion of expenditure at $24 \%, 18 \%$ and $17 \%$ respectively. This constituted $59 \%$ of the total family expenditure meaning that only $41 \%$ of expenditure was left for other uses such as clothing, healthcare, utilities, transport and other allocations such as investments, leisure, remittances and social activities. A comparison of mean income to mean expenditure revealed that the respondents spent approximately $15 \%$ more money than they earned. This implies that there was a possibility of some families being vulnerable to incurring debt and meeting basic needs using credit.

\section{Parental Support for Youth Livelihood Strategy}

The study sought to investigate whether parental support influenced the choice of youth livelihood strategies. Respondents were asked to indicate whether and how their parents or guardians supported their choice of livelihood strategies. The above half $(55 \%)$ of the respondents indicated that their parents and guardians supported their choice of livelihood strategy. The form of support by parents/guardians included the provision of education and training that was relevant to the livelihood strategy adapted, imparting life skills, role modelling, and encouragement in the establishment of income-generating activities through the provision of start-up capital. Forty-five per cent $(45 \%)$ of youth who indicated that parents and guardians did not influence their choice of livelihood strategy reported various reasons why their families were unable to support them. These reasons included the inadequate capacity of parents to support the youth due to their low levels of education and subsequent poverty. In some cases, the youth chose to assert their independence from parents by seeking out livelihood strategies on their own or by joining youth self-help groups in the local community.

\section{Hypothesis Test Results}

The first null hypothesis stated that there is no statistically significant relationship between family characteristics and youth livelihood outcomes. Table 4 presents the results of the Chi-Square test of association between family characteristics and youth livelihood outcomes.

Table 4: Chi-square results for family characteristics and youth livelihood outcomes

\begin{tabular}{llll}
\hline Variable & Chi-square $\left(\boldsymbol{\chi}^{\mathbf{2}}\right)$ & d.f. & Sig. $(\mathbf{p}$-level) \\
\hline Family size & 13.36 & 2 & $\mathrm{p}>0.05$ \\
Number of Dependents & $21.8^{*}$ & 2 & $\mathrm{p}<0.05$ \\
Aggregate family income (KSh.) & $32.54^{*}$ & 2 & $\mathrm{p}<0.05$ \\
Family expenditure (KSh.) & 2.37 & 2 & $\mathrm{p}>0.05$ \\
Maternal education & 9.72 & 3 & $\mathrm{p}>0.05$ \\
Paternal education & $15.38^{*}$ & 3 & $\mathrm{p}<0.05$ \\
Parental Support & $20.09^{*}$ & 2 & $\mathrm{p}<0.05$ \\
Aggregate value of family assets & $9.08^{*}$ & 3 & $\mathrm{p}<0.05$ \\
\hline
\end{tabular}

*Significant at $p<0.05$.

The results showed that five family factors had statistically significant relationship with youth livelihood outcomes namely: number of dependents, $\left(\chi^{2}=21.8 ;\right.$ d.f. $\left.=1 ; \mathrm{p}<0.05\right)$, family income, $\left(\chi^{2}=32.54\right.$; d.f. $\left.=1 ; \mathrm{p}<0.05\right)$, paternal level of education, $\left(\chi^{2}=15.38\right.$; d.f. $=3$; $\left.\mathrm{p}<0.05\right)$, parental support $\left(\chi^{2}=9.08\right.$; d.f. $\left.=3 ; \mathrm{p}<0.05\right)$ and aggregate value of family assets $\left(\chi^{2}=9.08\right.$; d.f. $\left.=3 ; \mathrm{p}<0.05\right)$. However, family size $\left(\chi^{2}=13.36\right.$; d.f. $\left.=2 ; \mathrm{p}>0.05\right)$, family expenditure $\chi^{2}=2.37$; d.f. $=2 ; \mathrm{p}>0.05$ and mothers' level of education $\chi^{2}=9.72$; d.f. $=3 ; p>0.05$ had no statistically significant relationship with youth livelihood outcomes. The results established that family income, paternal education, parental 
support, number of dependents and family assets had a statistically significant relationship with youth livelihood outcomes for this sample. The null hypothesis which posited that family characteristics had no statistically significant relationship with youth livelihood outcomes was therefore rejected.

\section{Family Predictors of Youth Livelihood Outcomes}

Further analysis was conducted to establish whether family characteristics could significantly predict youth livelihood outcomes. The second null hypothesis stated that family characteristics do not significantly predict youth livelihood outcomes. This hypothesis was tested by conducting ordered logistic regression (OLR) from which the resulting LR $\chi^{2}$ statistic and R-Square $\left(\mathrm{R}^{2}\right)$ were computed, as shown in Table 5.

Table 5: Ordinal Logistic Regression of YLO Against Family Characteristics

\begin{tabular}{lllll}
\hline Predictor Variables & & \multicolumn{2}{l}{ Estimated Coefficient } & \\
& & Odds Ratio( $(\boldsymbol{\beta})$ & Sig. $(\mathbf{p}>\mathbf{Z})$ & Z Stat. \\
\hline Aggregate family income & & $1.000329^{*}$ & 0.000 & 4.71 \\
Aggregate Family expenditure & & 1.000056 & 0.140 & 1.48 \\
Maternal education (base: None) & Primary & 0.126492 & 0.332 & -0.97 \\
& Secondary & 0.280213 & 0.205 & -1.27 \\
& Tertiary & 0.311857 & 0.148 & -1.28 \\
\cline { 2 - 5 } Paternal education (base: None) & Primary & 2.079639 & 0.087 & 1.06 \\
& Secondary & $1.603428^{*}$ & 0.016 & 3.43 \\
Parental support & Tertiary & 0.651524 & 0.835 & -1.18 \\
\cline { 2 - 5 } Family size & & $1.355275^{*}$ & 0.047 & 1.93 \\
Number of Dependents & & 1.107283 & 0.656 & 0.45 \\
Aggregate value of family assets & & $0.016371^{*}$ & 0.001 & -4.59 \\
R-Squared (R ${ }^{2}$ ) & & $1.000007^{*}$ & 0.019 & 2.34 \\
Log likelihood & & 0.7210 & & \\
LR chi-square & & -39.314269 & & \\
\hline Significant at $p<0.05$ & $203.18^{*}$ & 0.000 & \\
\hline
\end{tabular}

*Significant at $p<0.05$

Regression results established an R-squared $\left(\mathrm{R}^{2}\right)$ of 0.721 which indicated that family characteristics improved prediction power of youth livelihood outcomes by $72.1 \%\left(\mathrm{R}^{2}=0.721\right.$; Log-Likelihood Ratio of $\left(\chi^{2}=203.18 ;\right.$ d.f. $\left.=12 ; \mathrm{p}<0.01\right)$. The aggregate family income $(\beta=1.00, \quad \mathrm{p}=0.000)$, paternal education $(\beta=1.60, \mathrm{p}=0.016)$, parental support $(\beta=1.93, p=0.047)$, number of dependents $(\beta=0.02, p=0.001)$, and aggregate family assets $(\beta=1.00, \quad p=0.019)$ were the five family characteristics that were significant predictors of youth livelihood outcomes. This study established that family characteristics comprised of aggregate family income, paternal education, parental support, fewer dependents and family assets were significant predictors of youth livelihood outcomes. These results implied that that youth from middleincome families, whose fathers had acquired higher levels of education, and whose families had fewer dependents, had accumulated family assets and whose parents supported their livelihood strategies attained higher levels of youth livelihood outcomes than their counterparts who were less privileged on similar family characteristics. Therefore, the null hypothesis which posited that family characteristics did not predict youth livelihood outcomes was rejected. 


\section{DISCUSSION}

Capitals in the form of family characteristics in the study referred to family size, number of dependents, aggregate family income and expenditure, parental education; parental support and family assets. The variables that emerged as significant determinants of youth livelihood outcomes were the family size and number of dependents, paternal education, parental support, aggregate family income, and family assets.

\section{Family Size and Number of Dependents}

Youth-headed families in survival livelihood outcome level reported that they had more dependents such as their spouses, children, siblings and in-laws. This study has established that youth in survival livelihood outcome levels had more dependent members compared to the youth in the growth livelihood outcome level. This observation is significant given the fact that the study findings revealed that the number of dependants influenced livelihood outcomes negatively. These results implied that there was an inverse relationship between the number of dependents and youth livelihood outcomes. The youth whose livelihood outcomes were at the lowest survival level had the highest proportion of families with more dependents compared to the youth at the growth livelihood level who had fewer dependents. These findings concur with Grown and Sebstad (1989 who reported that the higher the number of dependents who rely on only one source of income to meet the basic household needs has an inverse relationship with livelihood outcomes. According to Chambers and Conway (1992), Carney (1998) and Chambers (1989) it is within vulnerability contexts and structural processes that livelihood are pursued which has a bearing on livelihood outcomes.

\section{Family Income and Expenditure}

The aggregate monthly income for a youth-headed family from all sources including salary, wage, gifts, remittances and sales was KSh. 22,258, whereas the average expenditure was KSh. 25,640 resulting in an average negative variance of KSh. 3,382 in the family budget. Family expenditure was conceptualised as money spent on food, clothes, shelter, healthcare, education, transport, utilities such as water, electricity and cooking fuel. For youth in survival livelihood level had a mean monthly income was KSh. 18,138 and a corresponding mean expenditure of KSh. 19,210. For youth in security livelihood levels, their mean monthly income was KSh. 21,444 and a corresponding mean expenditure of KSh. 18,400 respectively. Youth in growth livelihood level attained a higher mean monthly income of KSh. 26,598 and an average expenditure of KSh. 19,772 respectively. This implied that youth at security and growth livelihood levels had a higher income relative to their expenditures compared to youth at survival livelihood levels. Further analysis revealed that there were significant differences in income among youth by YLO where families with higher aggregate incomes being associated with youth at growth livelihood level.

An analysis of mean income to mean expenditure revealed that youth-headed families tended to spend approximately $15 \%$ more money than their monthly incomes. This pointed to the possibility of youthheaded families being vulnerable to accrued debts hence impeding their likelihood of achieving positive livelihood outcomes in the long run. Family expenditure by item established that basic needs such as food, education and rent combined consumed $59 \%$ share of expenditure while only $41 \%$ of expenditure was allocated to other purposes such as clothing, healthcare, utilities, transport, remittances and social activities. These findings are supported by Chambers (1989) and Carney et al. (1999) who reported that households spend the greatest share of the available income for basic needs and have little or no income allocated for savings and investments. According to Grown and Sebstad (1989), low-income mothers engage in 
strategies that may include changing patterns of consumption and income earning, involvement in the labour market, investing in social networks, domestic work and child-rearing rather than focusing on investment in the education of children and that of the household members.

\section{Parental Education and Youth Support}

Overall, the paternal level of education was generally higher than the maternal level of education of the youth in the study area. Further analysis revealed that there was a significant relationship between the paternal level of education and youth livelihood outcomes. About a third of youth in growth level had fathers with a tertiary level of education while only about a tenth of youth in survival livelihood level had fathers with similar educational attainment. There was, however, no significant relationship between the maternal level of education and youth livelihood outcomes. A relationship was also established between parental or guardian support of youth livelihood strategies and overall livelihood outcomes. A majority of youth in the growth livelihood level (62\%) enjoyed parental support of their livelihood strategy, which significantly differed from the youth in survival and security livelihood levels that lacked parental support. This positive influence by parents and guardians on youth livelihood strategy was in the form of advice in making career choices, imparting life skills, role modelling, education and providing capital for business start-ups. These findings concur with research by Schutte (2005) on emerging trends in urban livelihoods, and by Wahab, Odunsi and Ajiboye (2012) on causes and consequences of rapid erosion of cultural values in a traditional African society. These studies underscore the importance of the family as the basic social safety net in securing livelihoods and short-term "shock absorbers" for children before seeking external assistance. These findings are further supported by Juarez, Legrand, Lloyd, Singh and Hertrich (2013) who reported that youth transition to adulthood requires support from families and in particular from parents and the kinship network at large.

\section{Family Assets and Youth Livelihood Outcomes}

A comparison of family assets among the three youth livelihood outcome levels showed that the mean value of assets was higher among youth in growth level at KSh. 68,093 than in the security and survival YLO levels at KSh. 30,274 and KSh. 19,765 respectively. Youth in growth YLO level owned higher value assets compared to youth in security and survival livelihood levels. This study has established that family assets were used as a launching pad for the enhancement of youth livelihood outcomes or start-up capital for business enterprises. This implies that youth at the growth YLO levels had a head start in life in terms of support from their families to actualise their livelihood aspirations and subsequent outcomes, whereas those in security and survival YLO levels had to depend on themselves for their livelihoods. These study findings concur with those of Mago and Mago (2013) who reported that the major resource for livelihood enhancement is family assets. Household assets are vital for low-income families as they act as security in times of vulnerabilities, shocks and economic crisis due to poverty, unemployment or ill health. Zhan and Sherraden (2003) reported that family assets enable one to think and pursue long term goals in addition to having a positive personal and social effect on household well-being beyond consumption. This finding is further supported by Chambers (1989) who revealed that low-income households are only able to reduce their vulnerability through the utilisation of tangible and non-tangible assets.

\section{CONCLUSION}

This study has established that family characteristics had a significant effect on youth livelihood outcomes. The variables that emerged as significant determinants of youth livelihood outcomes were: a small family size, fewer dependents, higher levels of paternal education, 
parental support, increased aggregate family income, and increased value of family assets. These results implied that that youth from middle-income families, whose fathers had acquired higher levels of education, and whose families had fewer dependents, had accumulated family assets and whose parents supported their livelihood strategies attained higher levels of youth livelihood outcomes compared to their counterparts who were less privileged on similar family characteristics. The results of this study may be used to guide family and youth-focused interventions for the overall improvement of livelihood outcomes.

\section{ACKNOWLEDGEMENTS}

We wish to appreciate the support of the participants in this research.

\section{AUTHORS' CONTRIBUTIONS}

The first and second authors participated in the research process from research conception to the development of research tools, data collection, analysis and writing of the research report.

\section{REFERENCES}

Carney, D. (1998). Implementing the sustainable rural livelihoods approach. In: Carney, D. (Ed.), Sustainable rural livelihoods: What contribution can we make? (pp. 3-23), London, UK: Department for International Development.

Carney, D., Drinkwater, M., Rusinow, T., Neefjes, K., Wanmali, S. \& Singh, N. (1999). Livelihoods approaches compared: A brief comparison of the livelihoods approaches of the UK Department for International Development (DFID), CARE, Oxfam and the United Nations Development Programme (UNDP), London, UK: Department for International Development.
Chambers, R. (1989). Vulnerability: Coping and policy. London, UK: Institute of Development Studies Bulletin, 20 (2), 1-7.

Chambers, R. \& Conway, G. (1992). Sustainable rural livelihoods: practical concepts for the $21^{\text {st }}$ Century. University of Sussex, Institute for Development Studies, DP 296, Brighton.

Chiiran, G. G. (2014). Approaches to Guidance and Counselling and its Benefits to Youth: Kenyan Urban Experience. African Research Journal of Education and Social Sciences, 1 (1), 1-8.

Department for International Development [DFID]. (1999). Sustainable livelihoods guidance sheets. Available from the livelihoods learning platform. Retrieved on $8^{\text {th }}$ May 2020 from www.livelihoods.org.

Grown, C. A. \& Sebstad, J. (1989). Introduction toward a wider perspective on women's empowerment. World Development, 17(7), 937-952.

International Labour Office [ILO]. (2015). Global Unemployment Trends for Youth 2015: Scaling up investments in decent jobs for youth. Geneva, Switzerland.

Juarez, F., Legrand, T., Lloyd, C., Singh, S., \& Hertrich, V. (2013). Youth migration and transitions to adulthood in developing countries. The Annals of the American Academy of Political and Social Science, 648 (1), 6-15.

Mago, S. \& Mago, S. (2013). Asset-Building and Micro-finance: An Econometric Analysis. Mediterranean Journal of Social Sciences, 4 (3), 311-350.

Maisiba, F. M. \& Gongera, E. G. (2013). The Role of Youth Enterprise Development Fund (YEDF) in Job Creation: A Case of Dagoretti Constituency, Nairobi County, Kenya. 
Research Journal of Finance and Accounting, 4 (12), 240-289.

Meikle, S. (2002). The urban context and poor people. In Rakodi, C. \& Lloyd-Jones, T. (Eds.), Urban Livelihoods: A People-Centered Approach to Reducing poverty (pp. 37-51), London: Earthscan.

McKee, T. (1989). Micro-level strategies for supporting livelihoods, employment and income generation for poor women in the Third World: The challenge of significance. World Development, 177 (7), 993-1006.

Muiya, B. M. (2014). The Nature, Challenges and Consequences of Urban Youth Unemployment: A Case of Nairobi City, Kenya. Universal Journal of Educational Research, 2(7) 495503.

Njonjo, S. K. (2010). Youth Fact Book: Infinite Possibility of Definite Disaster? Institute of Economic Affairs and Friedrich-Ebert Stiftung, Nairobi: Elite Pre-Press Limited.

Omolo, O. J. (2011). Labour and Employment Inequalities in the Context of the East African Regional Integration Process. In Society for International Development, East African Integration: Dynamics of Equity in Trade, Education, Media and Labour. Nairobi: Ascent Limited.

Omolo, O.J. (2010). The Dynamics and Trends of Employment in Kenya. IEA Research Paper Series, No. 1/2010. Nairobi: Institute of Economic Affairs-Kenya.

Republic of Kenya (2008a). First Medium-Term Plan: Kenya Vision 2030- A Globally Competitive and Prosperous Kenya. Office of the Prime Minister, Minister of State for Planning, National Development and Vision 2030. Nairobi: Government Printer.
Republic of Kenya. (2008b). Sector Plan for Labor, Youth and Human Resource Development, 2008-2012. Ministry of Labor. Nairobi: Government Printer.

Republic of Kenya. (1969). National Development Plan, 1970-1974. Nairobi: Government Printer.

Republic of Kenya. (1965). Sessional Paper No. 10 of 1965 on African Socialism and its Application to Planning Kenya. Nairobi: Government Printer.

Scoones, I. (2009). Livelihoods perspectives and rural development. The Journal of Peasant Studies, 36(1), 171-196.

Schutte, S. (2005). Emerging trends in urban livelihoods. Kabul: Afghanistan Research and Evaluation Unit (AREU).

United Nations Human Settlement Programme [UN-Habitat]. (2015). Youth. [Online] Available: http://unhabitat.org/urbanthemes/youth/_[Accessed: July 1, 2020].

United States Agency for International Development (USAID). (2013). State of the field report: Examining the evidence in youth workforce development. Washington, D.C.: USAID.

Wahab, E. O., Odunsi, S. O., \& Ajiboye, O. E. (2012). Causes and Consequences of Rapid Erosion of Cultural Values in a Traditional African Society. Journal of Anthropology, http://dx.doi.org/10.1155/2012/327061

World Bank, (2015). Kenya Overview. [Online] Available: www.world bank.org en/ country/Kenya/overview [Accessed: July 1, 2020].

Zhan, M. \& Sherraden, M. (2003). "Assets, Expectations, and Children's Educational Achievements in Female-Headed Households". The Social Services Review, 77 (2), 45-69. 